\title{
Manajemen Pendidikan Anak Usia Dini (PAUD) dalam Rangka Meningkatkan Mutu Pembelajaran (Studi pada PAUD Negeri Pembina Curup dan PAUD Pertiwi Kabupaten Rejang Lebong)
}

\author{
Suharti \\ Dinas Pendidikan dan Kebudayaan Kabupaten Rejang Lebong \\ suhartimpd9@gmail.com
}

\begin{abstract}
This article aims to find comparison of PAUD management of Pembina Curup and PAUD Pertiwi Rejang lebonmg in improving the quality of learning with qualitative descriptive approach so as to obtain the following conclusion. Curriculum management, student affairs, educators and educational staff, facilities and infrastructure and PAUD financial management has been implemented by the PAUD Pembina and PAUD Pertivi. This is seen in. First, the quality of early childhood education is the service provided in the form of Kindergarten (TK) and Play Group (KB). Second, the fulfillment of the level of child development achievement, the learning is done in accordance with the age group of learners, and also in accordance with the needs of the surrounding community and the learners themselves. Third, the fulfillment of educators and educational personnel to meet the standards, even exceed the existing standards, by providing opportunities for educators to go to college and follow the training. Fourth, existing facilities and infrastructure are now more and more, both in terms of quantity and quality as required by the existing rules. Facilities and infrastructure about safe, comfortable, bright and fulfilling children's bealth criteria, according to the child's developmental level, make use of the available resources and potentials already fulfilled. Fifth, in accordance with the instructions and rules on the financial implementation of PAUD. Finance management of PAUD Terpadu and PAUD Pertiwi has also been communicated with parents, learners, and the community. So there is no rejection from the public.
\end{abstract}

Keywords : Educational Management, Quality of Learning, Early Childhood Education (PAUD)

\begin{abstract}
Abstrak: Artikel ini bertujuan menemukan perbandingan manajemen PAUD Negeri Pembina Curup dan PAUD Pertiwi Kabupaten Rejang lebonmg dalam meningkatkan mutu pembelajaran dengan pendekatana deskriptif kualitatif sehingga memperoleh simpulan sebagai berikut. Manajemen kurikulum, kesiswaan, pendidik dan tenaga kependidikan, sarana dan prasaran serta manajemen kenangan PAUD sudah dilaksanakan oleh PAUD Terpadu dan PAUD Pertivi. Hal ini terlihat pada, Pertama, mutu pembelajaran pendidikan anak usia dini yaitu layanan yang disediakan berupa kelompok Taman Kanak-Kanak (TK) dan Kelompok Bermain (KB). Kedua, Pemenuban tingkat pencapaian perkembangan anak, pembelajaran yang dilakukan yang sesuai dengan kelompok umur peserta didik, dan juga sesuai dengan kebutuhan masyarakat sekitar serta peserta didik itu sendiri. Ketiga, Pemenuban tenaga pendidik dan tenaga Kependidikan untuk memenubi standar, babkan melebibi standar yang ada, dengan cara memberi kesempatan pendidik. untuk. kuliah dan mengikuti diklat. Keempat, sarana dan prasarana yang ada sekarang sudah lebih dan cukup, baik itu dan segi kuantitas maupun kualitas yang disyaratkan sesuai aturan yang ada. Sarana dan prasarana tentang alat yang aman, nyaman, terang, dan memenubi kriteria kesehatan bagi anak, sesuai dengan tingkat perkembangan anak, memanfaatkan potensi dan sumber daya yang ada sudah terpenubi. Kelima, sesuai dengan petunjuk dan aturan tentang keuangan penyelenggaraan PAUD. Pengelolaan keuangan PAUD Terpadu dan Pertiwi, juga sudah dikomunikasikan dengan orang tua, peserta didik, dan masyarakat. Sehingga tidak ada penolakan dari masyarakat.
\end{abstract}

Kata Kunci : Manajemen Pendidikan, Mutu Pembelajaran, PAUD 


\section{Pendahuluan}

Anak usia dini merupakan periode awal yang paling mendasar dalam pertumbuhan dan perkembangan kehidupan manusia. Pada masa ini ditandai oleh berbagai periode penting yang menjadi dasar dalam kehidupan anak yang selanjutnya. Salah satu periode menjadi ciri masa usia dini adalah golden ages atau periode usia emas. Periode usia emas pada anak usia dini ditandai dengan munculnya masa eksplorasi, masa identifikasi / imitasi, masa peka, masa bermain dan masa trozt alter atau masa membangkang.

Konsep "golden ages" diperkuat oleh fakta yang ditemukan oleh ahli Neurologi yang menyatakan bahwa pada saat lahir otak bayi mengandung 100-200 miliar neuron atau sel saraf yang siap melakukan sambungan antar sel. Pertumbuhan jaringan otak mencapai $80 \%$ pada usia 3 tahun apabila banyak mendapatkan stimulus dan mencapai $85 \%$ pada usia 6 tahun, dan mencapai titik kulminasi 100\% ketika anak berusia 8 sampai 18 tahun. Pertumbuhan fungsional sel saraf tersebut membutuhkan berbagai situasi pendidikan yang mendukung, baik dalam situasi pendidikan, keluarga, masyarakat maupun sekolah. Para ahli pendidikanpun sepakat bahwa jika periode keemasan tersebut hanya berlangsung 1 kali sepanjang rentang kehidupan manusia. Hal ini menunjukkan bahwa berapa meruhinya suatu keluarga, masyarakat dan bangsa jika mengabaikan masa-masa penting yang berlangsung pada masa anak usia dini.

Komitmen antar bangsa terhadap pendidikan anak usia dini telah dicapai melalui berbagai momentum dan kesepakatan penting. Salah satunya deklarasi Dakkar, antara lain : (1) Menyepakati perlunya upaya memperluas dan memperbaiki keseluruhan perawatan dan pendidikan anak usia dini, terutama bagi anak-anak yang sangat rawan dan kurang beruntung. (2) Kesepakatan antar negara yang tergabung dalam perserikatan bangsa-bangsa menyepakati "dunia yang layak bagi anak 2002" atau dikenal dengan "world fit for children 2002". Secara operasional, kesepakatan tersebut tertuang dalam bentuk kebijakan-kebijakan : (1) Pencanangan hidup sehat, (2) Memberikan pendidikan yang berkualitas, (3) Memberikan perlindungan terhadap penganiayaan, eksploitasi dan kekerasan terhadap anak.

Pendidikan Anak Usia Dini menyatakan: Bahwa faktor sumber daya manusia amat menentukan keberhasilan pembangunan nasional, karena pembangunan itu dilaksanakan oleh manusia dan untuk mencapai tujuan yang dapat mensejahterakan manusia, kedudukan sumber daya manusia menempati sentral dalam pembangunan nasional, sehingga perhatian, dan daya serta usaha pemerintah dan masyarakat dipusatkan untuk membangun SDM yang memiliki keunggulan bagi bangsa Indonesia merupakan hal yang mendesak dan tidak dapat ditawar-tawar lagi. 
Dalam pengembangan SDM yang berkualitas tidak hanya meningkatkan kemampuan fisik, yang dapat dimanfaatkan untuk memenuhi kebutuhan-kebutuhan ekonomi, tetapi menurut Setiasih Masitoh, justru yang lebih penting adalah pengembangan kemampuan yang terfokus pada "Brain Power Planning" yang merujuk pada kontelasi keterampilan, sikap, perilaku mandiri, memiliki daya saing tinggi, dan tahan terhadap perubahan serta gejolak yang timbul akibat perubahan tersebut. Agar tercipta SDM yang berkualitas pada milenium ketiga ini, maka pendidikan merupakan kebutuhan utama yang harus dipenuhi. pendidikan tersebut hendaknya diberikan sejak usia dini, karena pada usia dini perlu ditumbuh kembangkan kreatifitas anak. ${ }^{1}$

Pentingnya pendidikan bagi anak usia dini didasarkan adanya berbagai hasil penelitian yang menyebutkan bahwa masa usia dini merupakan periode kritis dalam perkembangan anak. Berdasarkan kajian neurologi pada saat lahir otak bayi mengandung sekitar 100 milyar neuron yang siap melakukan sambungan antar sel. Selama tahun-tahun pertama, otak bayi berkembang sangat pesat dengan menghasilkan bertriliyun-triliyun sambungan antara neuron yang banyaknya melebihi kebutuhan. Smabungan ini harus diperkuat melalui berbagai rangsangan psikososial, karena sambungan yang tidak diperkuat akan mengalami atrofi (penyusutan) dan musnah. Inilah yang pada akhirnya akan mempengaruhi tingkat kecerdasan anak. Hal ini telah dibuktikan oleh hasil penelitian di Baylor College of Medicine yang menemukan bahwa apabila anak jarang memeproleh rangsangan pendidikan, maka perkembangan otaknya lebih kecil 20-30\% dari ukuran normal anak seusianya. Dalam kajian lain diungkapkan bahwa, sekitar 50\% kapabilitas kecerdasan manusia terjadi ketika anak berumur 4 tahun, $80 \%$ telah terjadi ketika berumur 8 tahun, dan mencapai titik kulminasi ketika anak berumur sekitar 18 tahun. Hal ini berarti bahwa perkembangan yang terjadi pada kurun waktu 14 tahun berikutnya, dan selanjutnya perkembang otak akan mengalami stagnasi.

Pengembangan pendidikan anak usia dini harus dilakukan secara terpadu untuk menolong masyarakat miskin dan memutus siklus kemiskinan antar generasi. Intervensi pendidikan meningkatkan kemungkinan kelangsungan hidup anak. Perpaduan keduanya akan mengoptimalkan pertumbuhan dan perkembangan anak sebagai pribadi yang utuh, yang dilakukan melalui upaya pemeliharaan kesehatan, pemberian nutrisi, stimulasi kecerdasan, penyediaan kesempatan yang luas bagi anak untuk bereksplorasi dan belajar secara menyenangkan, pengasuhan dan bimbingan anak untuk

\footnotetext{
${ }^{1}$ Masitoh, Setiasih, O., Djoehaeni, H., Pendekatan Belajar Aktif di Taman Kanak-kanak. (Jakarta: Ditjen Dikti Departemen Pendidikan Nasional. 2003)
} 
memahami potensi dirinya dan berperan aktif dalam keluarga serta masyarakat.

Sebagaimana tertuang dalam UU Sisdiknas Nomor 20 tahun 2003 pasal 1 butir 14, PAUD adalah suatu upaya pembinaan yang ditujukan kepada anak sejak lahir sampai dengan usia 6 tahun yang dilakukan melalui pemberian rangsangan pendidikan untuk membantu pertumbuhan dan perkembangan jasmani dan rohani agar anak memiliki kesiapan dalam memasuki pendidikan lebih lanjut. Untuk itulah suatu lingkungan dan keluarga seharusnya mampu memberikan fungsi pengasuhan, kasih sayang, dan dukungan kepada anak. ${ }^{2}$

Sejalan dengan hal di atas, fungsi pendidikan bagi anak usia dini tidak hanya sekedar memberikan berbagai pengalaman belajar seperti pendidikan pada orang dewasa, tetapi juga berfungsi mengoptimalkan perkembangan kapabilitas kecerdasannya. Pendidikan disini hendaknya diartikan secara luas, mencakup seluruh proses stimulasi psikososial yang tidak terbatas pada proses pembelajaran yang dilakukan secara klasikal. Artinya pendidikan dapat berlangsung dimana saja dan kapan saja, baik yang dilakukan sendiri dilingkungan keluarga maupun oleh lembaga pendidikan diluar lingkungan keluarga.

Merujuk dari berbagai penjelasan yang telah dikemukakan di atas, dengan melihat kondisi anak usia dini yang juga disebut sebagai potensi SDM suatu Negara, serta peran lingkungan disekitarnya yang berkaitan dengan pendidikan, maka keberadaan lembaga pendidikan anak usia dini baik yang bersifat formal dan nonformal yang diselenggarakan oleh masyarakat menjadi sangat penting dalam menyediakan rangsangan-rangsangan yang memungkinkan anak dapat menemukan hal-hal yang melampaui kemauannya. Salah satu jenis pendidikan yang memperhatikan perkembangan anak adalah Lembaga Pendidikan Anak Usia Dini atau lebih dikenal dengan singkatan PAUD.

PAUD Adalah wahana bermain sambil belajar yang penuh keceriaan dan kebebasan. Dengan demikian memungkinkan anak untuk berekspresi dan mengembangkan bakat, minat dan kreatifitasnya. Sekaligus juga mendapatkan pengetahuan keterampilan serta pengembangan sikap perilaku anak dalam suasana yang menyenengkan.

PAUD berfungsi membina, menumbuhkan, dan mengembangkan seluruh potensi yang dimiliki anak pada usia dini secara optimal sehingga terbentuk perilaku dan kemampuan dasar sesuai dengan tahap perkembangannya agar memiliki kesiapan untuk memasuki pendidikan

\footnotetext{
${ }^{2}$ Rindaningsih, Ida. "Pengembangan Model Manajemen Strategik Berbasis (beyond center and circle Time) BCCT Pada PAUD." PEDAGOGIA: Jurnal Pendidikan 1, no. 2 (2012): 213 223.
} 
selanjutnya. Salah satu jalur terselenggaranya PAUD adalah jalur pendidikan non-formal. ${ }^{3}$

Dalam rangka pengembangan program PAUD pemerintah dihadapkan pada berbagai masalah. Di samping permasalahan dana, masih terdapat berbagai permasalahan yang dihadapi oleh pemerintah. Pertama, masih rendahnya pemahaman masyarakat terhadap arti pentingnya PAUD bagi perkembangan anak selanjutnya. Kedua, belum semua daerah memiliki aparat yang secara khusus menangani pembinaan PAUD hingga ketingkat operasional. Ketiga, masih kurangnya tenaga kependidikan PAUD dilapangan. Disatu sisi kita kebanyakan pengangguran pendidikan, tetapi disisi lain tenaga yang memiliki kualifikasi sebagai tenaga kependidikan PAUD masih sangat kurang. Keempat, luasnya wilayah yang harus dilayani dan banyaknya daerah yang sulit dijangkau kendala geografis seringkali menjadi penyebab utama ketinggalan informasi dan tidak terjangkau layanan.

Bersadarkan berbagai uraian yang dikemukakan di atas dapat kita ketahui berbagai permasalahan yang dihadapi oleh lembaga pendidikan dalam rangka meningkatkan mutu pembelajaran dampak dari permasalahan yang muncul tersebut bisa dijadikan tolok ukur bagi kemajuan suatu lembaga yang menyelenggarakan Pendidikan Anak Usia Dini. Dalam proses pembelajaran Pendidikan Anak Usia Dini, hal ini tidak bisa terlepas dari manajemen penyelenggaraan yang baik, oleh karenanya pertanyaan yang timbul dihati peneliti adalah bagaimana manajemen penyelenggaraan program Pendidikan Anak Usia Dini di PAUD Terpadu Negeri Pembina dan PAUD Pertiwi Curup Kabupaten Rejang Lebong. Dewasa ini banyak terlihat lembaga yang menyelenggarakan program PAUD hanya bertahan 1-2 tahun saja, hal ini dikarenakan terbentur dengan masalah pendanaan dan kurangnya koordinasi antara lembaga dengan warga masyarakat sekitarnya.

Kasus seperti tersebut di atas juga terjadi di Kabupaten Rejang Lebong, hal ini terlihat oleh peneliti banyaknya lembaga PAUD yang tutup diakibatkan oleh minimnya dana yang dimiliki oleh lembaga tersebut. Selain itu, permasalahan yang mereka hadapi juga kurangnya ilmu pengetahuan mereka dalam mengelola PAUD sehingga tenaga pendidik dan kependidikan dalam lembaga tersebut tidak dapat bekerja secara professional. Berbeda dengan salah satu PAUD yang terdapat di Kabupaten Rejang Lebong yakni PAUD Terpadu Negeri Pembina dan PAUD Pertiwi. PAUD Terpadu Negeri Pembina beralamatkan di Jl. Basuki Rahmat No. 05 Dwi Tunggal Kecamatan Curup Kabupaten Rejang Lebong, dan PAUD Pertiwi beralamatkan di Jln.

\footnotetext{
${ }^{3}$ Rozalena, Rozalena, and Muhammad Kristiawan. "Pengelolaan Pembelajaran Paud dalam Mengembangkan Potensi Anak Usia Dini." JMKSP (Jurnal Manajemen, Kepemimpinan, dan Supervisi Pendidikan) 2, no. 1 (2017).
} 
Basuki Rahmat Dwi Tunggal Curup yang mana ditengah maraknya lembaga PAUD yang tutup diakibatkan berbagai permasalahan yang dihadapi, PAUD yang didirikan pada tahun 1995 ini tetap eksis dan berkibar. Dalam proses pembelajaran PAUD Terpadu Negeri Pembina menerapkan kurikulum pembelajaran anak yang diajarkan oleh tenaga pengajar dari lulusan S1 PAUD. Dari kasus-kasus yang telah diuraikan di atas, peneliti sangat tertarik untuk meneliti dan melihat lebih dekat mengenai langkah-langkah yang dilakukan oleh Pengurus PAUD Terpadu Negeri Pembina dan PAUD Pertiwi Kabupaten Rejang Lebong dalam menjalankan roda organisasinya sehingga dapat bertahan hingga saat ini. Hal ini tidak bisa terlepas dari manejemen penyelenggaraan yang baik, oleh karenanya pertanyaan yang timbul dihati peneliti adalah Bagaimana Manajemen Penyelenggaraan Program PAUD di PAUD Terpadu Negeri Pembina dan PAUD Pertiwi Kabupaten Rejang Lebong.

Berdasarkan latar belakang di atas maka permasalahan peneliti mengambil fokus kepada "Bagaimana perbandingan manajemen PAUD dalam rangka meningkatkan mutu pembelajaran antara PAUD Terpadu Negeri Pembina dengan PAUD Pertiwi Kabupaten Rejang Lebong ? Permasalahan penelitian yang tersebut diatas dapat dijabarkan dalam bentuk pertanyaan sebagai berikut: Bagaimanakah perbandingan manajemen kurikulum dalam meningkatkan mutu pembelajaran antara PAUD Terpadu Negeri Pembina dan PAUD Pertiwi Kabupaten Rejang Lebong? Bagaimanakah perbandingan manajemen kesiswaan dalam peningkatan mutu pembelajaran antara PAUD Terpadu Negeri Pembina dan PAUD Pertiwi Kabupaten Rejang Lebong?. Bagaimanakah perbandingan manajemen tenaga pendidik dan tenaga kependidikan dalam meningkatkan mutu pembelajaran antara PAUD Terpadu Negeri Pembina dan PAUD Pertiwi Kabupaten Rejang Lebong?. Bagaimanakah perbandingan manajemen sarana dalam meningkatkan mutu pembelajaran antara PAUD Terpadu Negeri Pembina dan PAUD Pertiwi Kabupaten Rejang Lebong?. Bagaimanakan perbandingan manajemen keuangan dalam peningkatan mutu pembelajaran antara PAUD Terpadu Negeri Pembina dan PAUD Pertiwi Kabupaten Rejang Lebong?

Tujuan umum penelitian ini untuk membandingkan manajemen PAUD dalam peningkatan mutu pembelajaran antara PAUD Terpadu Negeri Pembina dan PAUD Pertiwi Kabupaten Rejang Lebong. Berdasarkan tujuan umum diatas, adapun tujuan khusus dari penelitian ini adalah untuk membandingkan : Manajemen kurikulum dalam meningkatkan mutu pembelajaran. Manajemen kesiswaan dalam meningkatkan mutu pembelajaran. Manajemen pendidik dan tenaga kependidikan dalam meningkatkan mutu pembelajaran. Manajemen sarana dalam meningkatkan 
mutu pembelajaran. Manajemen keuangan dalam meningkatkan mutu pembelajaran.

Secara teori kegunaan penelitian ini dari segi teoritis Secara teoritis penelitian ini bermanfaat untuk mengembangkan konsep manajemen program PAUD yang efisien dan efektif. Konsep tersebut akan menjadi acuan dasar para peneliti dan pengembangan dalam manajemen penyelenggaraan program PAUD. Secara Praktis hasil Penelitian ini diharapkan mampu memberikan informasi/acuan dasar bagi para kepala program PAUD dalam rangka merumuskan strategi alternatif dalam meningkatkan mutu manajemen program PAUD. Sebagai masukan bagi Dinas Pendidikan dan Kebudayaan tingkat Propinsi/Kabupaten/Kota dalam menyelenggarakan program PAUD.

\section{Metode Penelitian}

Dalam penelitian ini peneliti menggunakan penelitian deskriptif perbandingan yaitu dengan mendeskripsi perbandingan data yang diperoleh dari masing-masing kedua lembaga dengan melihat perbedaan dan persamaan dalam memanage lembaga yang diolah. Arikunto peneliti komparasi akan dapat menemukan persamaan-persamaan, perbedaan tentang benda-benda, tentang orang-orang, tentang prosedur kerja, tentang ide-ide, kritik-kritik terhadap orang, kelompok terhadap suatu ide atau suatu prosedur kerja, tentang ide-ide, kritik-kritik terhadap orang, kelompok terhadap suatu ide atau suatu prosedur kerja. V an Dale juga mengungkapkan tentang penelitian komperatif dalam Arikunto, ${ }^{4}$ mengungkapkan tentang jenis-jenis interrelationship studi yang membandingkan dua atau tiga kejadian dengan melihat penyebab-penyebabnya. Diharapkan penelitian ini akan dapat memberikan informasi tentang Manajemen PAUD.

Data yang dikumpulkan melalui observasi, wawancara, dan studi dokumentasi. Subyek penelitian ini adalah Kepala dan Guru. Alasan pemilihan ini karena pihak-pihak tersebut mewakili obyek penelitian yaitu bidang manajemen penyelenggaraan PAUD Terpadu Negeri Pembina dan PAUD Pertiwi Kabupaten Rejang Lebong Menurut Arikunto (2002:116) subyek penelitian adalah benda, hal, atau orang, tempat data untuk variable penelitian melekat, dan dipermasalahkan.

Teknik pengumpulan data dilakukan dengan metode observasi, wawancara dan studi dokumentasi. Tahapan analisis data dimulai dengan mengumpulkan seluru sumber data, selanjutnya dilakukan reduksi data dengan mengklarifikasikan dan membuang data yang tidak perlu. Tahap

\footnotetext{
${ }^{4}$ Suharsimi Arikunto, Prosedur Penelitian (Suatu Pendekatan Praktik). (Jakarta : Rineka Cipta. 2002), 237
} 
berikutnya adalah pengegambilan kesimpulan yang merupakan usaha menemukan makna dari unsur-unsur data yang disajikan.

\section{Hasil dan Pembahasan Penelitian}

Pendidikan Anak Usia Dini merupakan jembatan antara lingkungan keluarga dengan masyarakat yang lebih luas yaitu Sekolah Dasar dan lingkungan lainnya dengan tujuan untuk memfasilitasi pertumbuhan dan keterampilan anak secara menyeluruh atau menekankan pada pengembangan seluruh aspek kepribadian anak. ${ }^{5}$ Oleh karena itu pendidikan untuk anak usia dini khususnya di Taman Kanak-Kanak perlu menyediakan berbagai kegiatan yang dapat mengembangkan berbagai aspek keterampilan anak. Paling tidak hal-hal yang harus difahami oleh pendidik dalam pembelajaran pendidikan anak usia dini adalah:

Pertama, Pembelajaran merupakan aktualisasi kurikulum yang menuntut aktivitas guru dalam menciptakan dan menumbuhkan kegiatan sesuai dengan rencana yang telah diprogramkan. M. Solehuddin mengatakan bahwa “ Instruction its thus implementation of curriculum plan, usualy, but not necessarly, involving teaching in the sense of student, teacher interaction in an educational setting". 6 dalam hal ini, guru harus dapat mengambil keputusan dasar penilaian yang tepat ketika anak didik belum dapat membentuk kompetensi dasar, apakah kegiatan pembelajaran dihentikan, diubah modelnya, atau mengulang dulu pembelajaran yang lalu.

1. Pembelajaran Berbasis Perkembangan

Pembelajaran anak usia dini yang diselenggarakan dilembagalembaga PAUD cenderung dilakukan secara formal, dengan orientasi pada guru, serta penekanan pada kemampuan membaca, menulis, dan berhitung. Pembelajaran berbasis perkembangan mengacu pada tiga hal penting, yaitu usia, karakteristik anak secara individual dan konteks social budaya anak. Dalam implementasinya, pembelajaran berbasis perkembangan menekankan pada hal-hal sebagai berikut : (1) Perkembangan anak secara holistic, (2) Program individual, (3) Pentingnya inisiatif anak, (4) Fleksibel, ketika lingkungan kelas menstimulassi anak, (5) Bermain sebagai wahana belajar, (6) Kurikulum terpadu, (7) Penilaian berkesinambungan, dan (8) Bermitra dengan orang tua dan masyarakat untuk mendukung perkembangan anak usia dini.

Pembelajaran berbasis perkembangan dapat dilakukan dengan prinsip-prinsip sebagai berikut :

\footnotetext{
${ }^{5}$ LOMBE, TK PERTIWI. "JURNAL Smart PAUD." Jurnal Smart PAUD 1, no. 1 (2018).

${ }^{6}$ M. Solehuddin, Konsep Dasar Pendidikan pra Sekolah (Bandung: Fakultas Ilmu Pendidikan UPI 1997)
} 
a. Menciptakan iklim kondusif dalam belajar.

b. Membantu kekentalan kelompok dan memenuhi kebutuhan individu.

c. Memberi keterampilan kepada anak untuk berpatisipasi aktif, mengambil inisiatif, melakukan eksplorasi terhadap objek dan lingkungan.

d. Memberikan kesempatan kepada anak untuk memilih kegiatanya sendiri, dengan memberikan pengalaman belajar yang dirancang secara kontek.

e. Mendorong anak-anak untuk mengembangkan keterampilan berkomunikasi dan berbahasa secara menyeluruh yang meliputi kemampuan berbicara, mendengar, membaca, dan menulis dini.

f. Memberikan motivasi dan membimbing agar anak mengenal lingkungannya, mengembangkan keterampilan social pengendalian dan disiplin diri.

2. Pembelajaran Berbasis Sentra

Menurut Arifin Metode sentra adalah metode yang digunakan untuk melatih perkembangan anak dengan menggunakan pendekatan bermain (Depdiknas, 2005) yang sering disebut sebagai playing with learn atau learning through play. ${ }^{7}$ Pembelajaran berbasis sentra adalah model pembelajaran yang dilakukan di dalam "lingkaran" (circle times) dan sentra bermain. Lingkaran adalah saat ketika guru duduk bersama anak dengan posisi melingkar untuk memberikan pijakan kepada anak yang dilakukan sesuudah atau sebelum bermain. Sentra bermain adalah zona atau area bermain anak yang dilengkapi dengan seperangkat alat bermain. Sentra bermain terdiri dari hal-hal sebagai berikut :

a. Bahan Alam dan Sains

Bahan-bahan yang diperlukan untuk disentra ini adalah daun, ranting, kayu, pasir, air, batu dan biji-bijian. Alat yang digunakan adalah sekop, saringan, corong, dan ember.

b. Balok

Dengan menyusun atau menggunakan balok anak dapat mengembangkan kemampuan logika matematika permulaan, kemampuan berfikir, dan memecahkan masalah.

c. Seni

d. Musik

3. Model Pembelajaran

7 Arifin, Ar-Raisul Karama, and Nur Ainy Fardana. "Peran Pendidik PAUD dalam Mengimplementasikan Pendidikan Karakter Melalui Metode Pembelajaran Sentra dan Lingkaran." Jurnal Psikologi Pendidikan dan Perkembangan 3, no. 3 (2014). 
Model pembelajaran adalah suatu pola atau rancangan yang ,mengambarkan proses perincian dan penciptaan situasi lingkungan yang memungkinkan anak berinteraksi dalam pembelajaran sehingga terjadi perubahan atau perkembangan.

4. Prosedur Pembelajaran

Prosedur pembelajaran yang paling mutakhir dilembaga-lembaga pendidikan anak usia dini, yakni prosedur pembelajaran berbasis sentra. Selajutnya, secara realitas guru dapat mengembangkannya sesuai kebutuhan serta karakteristik perserta didik dan lingkungan masingmasing.

Prosedur pembelajaran dalam pendidikan anak usia dini pada umumnya mengacu pada prosedur umur yang mencakup; pengelolaan kelas, prosedur kegiatan, dan penilaian.

a. Pengelolaan Kelas

Pengelolaan kelas dalam bahasa Inggris diistilahkan sebagai Classroom Management, itu berarti istilah pengelolaan identik dengan manajemen. Pengertian pengelolaan atau manajemen pada umumnya yaitu kegiatan-kegiatan meliputi perencanaan, pengorganisasian, pengarahan, pengkoordinasian, pengawasan, dan penilaian. Wilford A. Weber mengemukakan bahwa "Classroom management is a complex set of behaviors the teacher uses to establish and maintain classroom conditions that will enable students to achieve their instructional objectives efficiently - that will enable them to learn."'

Definisi di atas menunjukkan bahwa pengelolaan kelas merupakan seperangkat perilaku yang kompleks dimana guru menggunakan untuk menata dan memelihara kondisi kelas yang akan memampukan para siswa mencapai tujuan pembelajaran secara efisien. Lebih lanjut Wilford mengemukakan mengenai pandanganpandangan yang bersifat filosofis dan operasional dalam pengelolaan kelas : 1) pendekatan otoriter : siswa perlu diawasi dan diatur; 2) pendekatan intimidasi : mengawasi siswa dan menertibkan siswa dengan cara intimidasi; 3) pendekatan permisif : memberikan kebebasan kepada siswa, apa yang ingin dilakukan siswa, guru hanya memantau apa yang dilakukan siswa; 4) pendekatan resep masakan : mengikuti dengan tertib dan tepat hal-hal yang sudah ditentukan, apa yang boleh dan apa yang tidak; 5) pendekatan pengajaran : guru menyusun rencana pengajaran dengan tepat untuk menghindari permasalahan perilaku siswa yang tidak diharapkan; 6) pendekatan 64-80.

${ }^{8}$ Surjana, Andyarto. "Efektivitas pengelolaan kelas." Jurnal Pendidikan Penabur 1, no. 1 (2002): 
modifikasi perilaku : mengupayakan perubahan perilaku yang positif pada siswa; 7) pendekatan iklim sosio-emosional : menjalin hubungan yang positif antara gurusiswa ; 8) pendekatan sistem proses kelompok/dinamika kelompok : meningkatkan dan memelihara kelompok kelas yang efektif dan produktif.'

Dari kedelapan pendekatan tersebut yang akan mengoptimalisasikan pengelolaan kelas adalah pendekatan modifikasi perilaku, iklim sosio-emosional, dan sistem proses kelompok. Pengelolaan kelas yang meliputi ruangan maupun pengorganisasian perserta didik sesuai dengan kebutuhan daan program yang direncanakan akan membantu pencapaian standar kompetensi dan kompentensi dasar, serta tujuan pembelajaran secara optimal.

b. Prosedur Kegiatan

Pembelajaran anak usia dini dapat dilakukan dengan langkah-langkah sebagai berikut:

1) Sebelum Masuk Kelas

Setiap hari pada saat kedatangan, anak-anak disambut oleh guru dengan ramah dan penuh kasih sayang, mereka saling berjabat tangan dengan guru - guru dan teman - temannya sambil mengucapkan salam, lalu menyimpan tas mereka masing- masing di tempaat yang telah disediakan.

Setelah tanda masuk kelas, anak - anak berbaris dengan rapi dan salah satu anak memimpin didepan, kemudian mereka masuk dengan tertib.

2) Pendahuluan

Biasanya kegiatan pendahuluan dilaksanakan secara klasikal dan diikuti oleh seluruh anak dalam satu kelas, dalam waktu dan kegiatan yang sama. Kegiatan pendahuluan merupakan pemanasan, misalnya bercerita, bercakap - cakap dan tanya jawab seputar pengalaman mereka.

3) Kegiatan Inti

Kegiatan ini merupakan proses pembentukan kompetensi sesuai dengan tujuan pembelajaran, yang melibatkan perhatian, kemampuan social dan emosional. Kegiatannya mencakup berbagai macam permainan yang dipilih dan disukai anak agar dapat bereksplorasi, berimprovisasi, bereksperimen, meningkatkan pengertian, kosentrasi, memunculkan inisiatif, kemandirian dan kreativitasnya serta dapat membantu dan mengembangkan kebiasaan kerja yang efektif. 
4) Makan dan Istirahat

Sebelum makan anak - anak dibiasakan dengan mencuci tanggan, setelah di dalam kelas anak - anak berdoa bersama, kemudian makan bersama yang dibawa sendiri atau yang telah disediakan sekolah, setelah makan anak istirahat dan bermain dengan fasilitas permainan yang ada disediakan.

5) Penutup

Kegiatan penutup dilakukan untuk menengkan anak di berikan secara klasikal, misalnya menengarkan cerita, menyanyi dan melakukan apresiasi music. Kegiatan ini dapat diakhiri dengan tanya jawab mengenai kegiatan yang berlangsung sehingga anak dapat memaknai kegiatan yang telah dilaksanakan.

c. Penilaian

Selama pembelajaran berlangsung guru hendaknya mencatat setiap kejadian, baik yang berkaitan dengan pelaksanaan program pembelajaran maupun yang berkaitan dengan perkembangan perserta didik. Cacatan guru ini dapat digunakan sebagai bahan refleksi dan sebagai bahan masukan bagai keperluan penilaian.

Depdiknas memberikan pengertian: " Kelompok bermain adalah salah satu bentuk layanan pendidikan bagi anak usia $4-6$ tahun yang berfungsi untuk membantu meletakan dasar-dasar kearah perkembangan sikap, pengetahuan dan keterampilan yang diperlukan bagi anak usia dini dalam menyesuaikan diri dengan lingkungarmya dan untuk pertumbuhan serta perkembangan selanjutnya, termasuk siap memasuki pendidikan dasar". ${ }^{10}$

Taman Kanak-Kanak adalah adalah salah satu bentuk Pendidikan Anak Usia Dini (PAUD) pada jalur formal yang menyelenggarakan program pendidikan bagi anak usia 4-6 tahun. Dan hasil wawancara penelitian yang melibatkan kepala PAUD, guru-guru PAUD, orang tua peserta didik, dan peserta didik sendiri dapat disimpulkan bahwa manajemen pengelolaan peserta didik pada PAUD Terpadu Negeri Pembina dan Pertiwi yaitu Taman Kanak-Kanak (TK) dan Kelompok Bermain (KB) sudah memenuhi standar pelayanan peserta didik dan sesuai dengan kebutuhan masyarakat sekitar.

Kedua, manajemen Kesiswaan dalam Meningkatkan Mutu Pembelajaran. Setiap anak manusia yang dilahirkan didunia telah dilengkapi dengan berbagai potensi, meskipun demikian, berbagai potensi tersebut tidak akan berkembang dengan baik tanpa lingkungan yang kondusif dan bantuan dari orang dewasa disekitarnya. Fantasi anak telah muncul sejak usia dini, dan akan berkembang dalam rentang 3 tahun sampai 6 tahun. Maka pada usia 3

${ }^{10}$ Depdiknas. 2002. Kecerdasan Spiritual Dalam Membantu Prilaku Anak, Buletin PAUD Jurnal Ilmiah Anak Usia Dini Edisi Perdana. Jakarta : Direktorat PAUD Ditjen PLSP. 
sampai 6 tahun adalah masa dimana kita bisa mengajarkan/mengarahkan anak pada kemampuan dan potensi anak.

Dari hasil wawancara peneliti dengan kepela PAUD Pertiwi dan PAUD pembin, guru-guru, orang tua, dan peserta didik dapat diketahui bawah PAUD sudah berusaha melakukan pengelolaan dalam hal pemenuhan standar tingkat pencapaian perkembangan anak, dan sesuai dengan kelompok umur peserta didik. Sebagai contoh, peserta didik dikelompokkan pada kelompok yang sesuai dengan umur mereka, kemudian layanan yang diberikan disesuaikan dengan lingkup perkembangan peserta didik. Nilai-nilai Agama dan Moral, Sosial Emosional dan Kemampuan Dasar, dalam merespons hal-hal yang terkait dengan nilai agama dan moral, dapat diberikan untuk anak umur mulai 4 tahun. Untuk anak di bawah 4 tahun, lebih difokuskan pada perkembangan motorik balus dan motorik kasarnya.

Adapun 9 (Sembilan) kemampuan anak belajar anak usia dini tersebut, meliputi:

1. Kecerdasan linguistik (linguistik intelligence) yang dapat berkembang bila dirangsangkan melalui berbicara, mendengarkan, membaca, menulis, berdiskusi, dan bercerita.

2. Kecerdasan logika-matematik (logica-mathematical intelligence) yang dapat dirangsang melalul kegiatan menghitung, membedakan bentuk, menganalisis data, dan bermain dengan benda-benda.

3. Kecerdasan visual-spasial (visual-spatial intelligence) yang dapat dirangsang melalui bermain bolak-balik dan bentuk-bentuk geometri melengkapi puzzle, menggambar. melukis, menonton film maupun bermain bermain dengan daya khayal (imijinasi).

4. Kecerdasan musikal (musicallrhythmic intelligence) yang dapat dirangsang melalui melalui irama, nada, birama, berbagai bunyi dan bertepuk tangan.

5. Kecerdasan linguistik (bodily/kinesthic intelligence) yang dapat dirangsang melalui gerakan, tarian, olahraga, dan terutama gerakan tubuh.

6. Kecerdasan naturalis (naturalist intelligence) yaitu mencintai keindahan alam, yang dapat dirangsang melalui pengamatan lingkungan, bercocok tanam, memelihara binatang, termasuk mengamati fenomena alam seperti hujan, banjir, pelangi, siang malam, bulan, matahari.

7. Kecerdasan interpersonal (intrapersonal intelegence) yaitu kemampuan untuk melakukan hubungan antar manusia (berkawan) yang dapat dirangsang melalui bermain bersama teman, bekerja sama, bermain peran, dan memecahkan masalah, serta menyelesaikan konflek. 
8. Kecerdasan spiritual (spiritual intelligence) yaitu kemampuan mengenal dan ciptaan Tuhan, yang dapat dirangsang melalui penanaman nilai-nilai moral agama. ${ }^{11}$

Dengan demikian dapat disimpulkan bahwa manajemen yang dilakukan pada PAUD Negeri pembina dan PAUD Pertiwi sudah sesuai dalam hal pemenuhan standar tingkat pencapaian perkembangan anak, dan sesuai dengan kelompok umur peserta didik, dan juga sesuai dengan kebutuhan masyarakat sekitar dan peserta didik itu sendiri.

Ketiga, manajemen Pendidik dan Tenaga Kependidiakan dalam Meningkatkan Mutu Pembelajaran, Dari hasil wawancara peneliti dengan kepala PAUD Terpadu Negeri pembina dan PAUD Pertiwi, guru-guru, orang tua, dan peserta didik dapat diketahui bawah PAUD sudah berusaha melakukan pengelolaan tenaga pendidik dan tenaga kependidikan pada PAUD. Pendidik yang ada di PAUD Terpadu dan PAUD Pertiwi diberi kesempatan untuk meningkatkan kualifikasi akademiknya, dari hanya tamatan SMA diberi kesempatan untuk kuliah D-2 PGTK bahkan S-I PAUD. Selain itu pendidik PAUD Terpadu dan PAUD Pertiwi juga diberi kesempatan untuk mengikuti penataran atau pendidikan dan pelatihan yang dilakukan dinas pendidikan dan instansi lainnya. Kualifikasi dan kompetensi guru PAUD didasarkan pada Peraturan Menteri Pendidikan Nasional Republik Indonesia Nomor 16 tahun 2007 tentang Standar Kualifikasi Akademik dan Kompetensi Guru beserta lampirannya. Bagi guru PAUD jalur pendidikan formal (TK, RA, dan yang sederajat) dan guru PAUD jalur pendidikan nonformal (TPA, KB, dan yang sederajat) yang belum memenuhi kualifikasi akademik dan kompetensi disebut Guru Pendamping.

a. Standar Pendidik

1. Kualifikasi Akademik dan Kompetensi Guru

Kualifikasi dan kompetensi guru PAUD didasarkan dengan peraturan Menteri Pendidikan Nasional Republik Indonesia Nomor 16 tahun 2007 tentang Sstandar Kualifikasi Akademik dan Kompetensi Guru serta lampirannya.

Bagi guru PAUD jalur pendidikan formal (TK, RA, dan yang sederajat) dan Guru PAUD jalur pendidikaan nonformal (TPA, KB, dan yang sederajat) yang belum memenuhi kualifikasi akademik dan kompetensi disebut dengan Guru Pendamping atau Pengasuh.

2. Kualifikasi Akademik dan Kompetensi Guru Pendamping

a) Kualifikasi Akademik

Kualifikasi Akademik dan Kompetensi Guru Pendamping

PAUD harus: 1) memiliki ijazah D-II PGTK dari Perguruan 
Tinggi terakreditasi; atau 2) memiliki ijazah minimal Sekolah Menengah Atas (SMA) atau sederajat dan 3) memiliki sertifikat pelatihan pendidikan kursus PAUD yang terakreditasi.

b) Kompetensi

Kompetensi Guru Pendamping PAUD yaitu 1) Kompetensi Kepribadian, 2) Kompetensi Profesional, 3) Kompetensi Pedagogik, dan 4) Kompetensi Sosial.

3. Pengasuh PAUD

a) Kualifikasi Akademik

Memiliki kualifikasi akademik minimum Sekolah Menengah Atas (SMA) dan sederajat.

b) Kompetensi

Kompetensi pengasuh PAUD yaitu : 1) Memahami dasardasar pengasuhan. 2) Terampil melakukan/melaksanakan pengasuhan. 3) Bersikap dan berprilaku sesuai dengan kebutuhan psikologis anak.

Standar Tenaga Kependidikan

c) Pengawas/Penilik

Kualifikasi dan kompetensi Pengawas PAUD jalur pendidikan formal didsarkanpada peraturan Menteri Pendidikan Nasional Republik Indonesia Nomor 12 Tahun 2007 tentang Standar Pengawas Sekolah/Madrasah berserta lampirannya.

Kualifikasi dan kompetensi pemilik PAUD jalur pendidikan nonformal didasarkan pada Peraturan Pemilik Pendidikan nonformal pada umumnya.

d) Kepala PAUD Jalur Pendidikan Formal

Kualifikasi dan kompetensi kepala TK/RA didasarkan Peraturan Menteri Pendidikan Nasional Republik Indonesia Nomor 13 tahun 2007 tentang Standar Kepala Sekolah/Madrasah berserta lampirannya.

e) Pengelola PAUD Jalur Pendidikan Nonformal

Pengelola PAUD jalur pendidikan nonformal adalah penanggung jawab dalam satuan PAUD jalur pendidikan nonformal dengan kualifikasi :

1. Minimal memiliki kualifikasi dan kompetensi guru pendamping

2. Berpengalaman sebagai pendidik PAUD minimal 2 tahun.

3. Lulus pelatihan/magang/kursus pengelolaan PAUD dari lembaga terakreditasi.

Selain memiliki kompetensi guru pendamping, pengelola PAUD harus memiliki/memenuhi kompetensi sebagai berikut : 1) Kompetensi kepribadian. 2) Kompetensi Profesional. 3) Kompetensi Manajerial. 4) 
Kompetensi Sosial. Jadi dapat disimpulkan bahwa pengelolaan dalam hal mengelola pendidik dan tenaga kependidikan pada PAUD Terpadu dan PAUD Pertiwi sudah dilakukan dengan cukup baik. Pemenuhan tenaga pendidik dan tenaga pendidikan untuk memenuhi standar yang ada, bahkan melebihi standar yang ada sudah cukup banyak dilakukan oleh kepala PAUD Terpadu dan PAUD Pertiwi. Bahkan untuk melayani peserta didik yang cukup banyak, pihak kepala mengatur sedemikian rupa supaya tenaga pendidik yang ada dapat terakomodasi dengan baik.

Keempat, manajemen sarana dalam meningkatkan mutu pembelajaran. Dari hasil wawancara peneliti dengan kepala PAUD Terpadu dan PAUD Pertiwi, guru-guru, orang tua, dan peserta didik dapat diketahui bawah PAUD sudah berusaha mengelola sarana dan prasarana. Semua dana bantuan yang diperuntukan untuk sarana dan prasarana, telah digunakan sebagaimana mestinya. Sebagian sarana harus dipesan sampai ke luar daerah, sebagian lagi dapat dibuat di daerah sekitar PAUD, yang tentunya sesuai dengan petunjuk dan kepala PAUD, baik itu dan segi kualitas maupun kuantitas. Selain kondisi keamanan sarana prasarana juga sudah di perhatikan secara mendalam. bahkan sarana dan prasarana pada PAUD sudah lebih dan cukup, sehingga PAUD Terpadu menjadi salah satu PAUD Unggulan Kabupaten yang diusulkan kepada Propinsi.

Standar sarana dan prasarana, pengelolaan, dan pembiayaan merupakan satu kesatuan yang tidak dapat dipisahkan dalam mendukung pelayanan PAUD. Standar sarana dan prasarana meliputi jenis, kelengkapan, dan kualitas fasilitas yang digunakan dalam menyelenggarakan proses penyelenggaraan PAUD. Standar pengelolaan merupakan kegiatan manajemen satuan lembaga PAUD yang berkaitan dengan perencanaan, pelaksanaan, dan pengawasan penyelenggaraan PAUD. Sarana dan prasarana adalah perlengkapan untuk mendukung penyelenggaraan kegiatan pendidikan, pengasuhan, dan perlindungan. Pengadaan sarana dan prasarana perlu disesuaikan dengan jumlah anak, kondisi sosial, budaya, dan jenis Iayanan PAUD.

a. Prinsip adalah :

1) Aman, nyaman, terang, dan memenuhi kriteria kesehatan bagi anak.

2) Sesuai dengan tingkat perkembangan anak.

3) Memanfaatkan potensi dan sumber daya yang ada di Iingkungan sekitar, termasuk barang bekas layak pakai.

b. Persyaratan adalah:

Untuk PAUD Jalur Pendidikan Formal:

1) Luas lahan minimal $300 \mathrm{~m}^{2}$.

2) Memiliki ruang anak dengan rasio minimal $3 \mathrm{~m}^{2}$ per peserta didik, ruang guru, ruang kepala sekolah, tempat UKS, jamban dengan air 
bersih, dan ruang lainnya yang relevan dengan kebutuhan kegiatan anak.

3) Memiliki alat permainan edukatif, baik buatan guru, anak, dan pabrik.

4) Memiliki fasilitas permainan baik di dalam maupun di luar ruangan yang dapat mengembangkan berbagai konsep.

5) Memiliki peralatan pendukung keaksaraan.

Jadi dapat disimpulkan bahwa pengelolaan sarana dan prasarana sudah dilakukan oleh kepala PAUD Terpadu Negeri Pembina dan Pertiwi. Sehingga sarana yang ada sekarang sudah Iebih dari cukup, baik itu dan segi kuantitas maupun kuantitas yang disyaratkan sesuai aturan yang ada. Selain prinsip sarana dan prasarana tentang alat yang aman, nyaman, terang, dan memenuhi kriteria kesehatan bagi anak, sesuai dengan tingkat perkembangan anak, memanfaatkan potensi dan sumber daya yang ada sudah terpenuhi.

Kelima, manajemen keuangan dalam meningkatkan mutu pembelajaran. Dari hasil wawancara peneliti dengan kepala PAUD Terpadu Negeri Pembina dan Pertiwi, guru-guru, orang tua, dan peserta didik dapat diketahui bawah PAUD sudah berusaha melakukan manajemen dalam hal pembiayaan untuk pengelolaan PAUD. Sebagai contoh, karena keterbatasan biaya yang dapat di sediakan oleh masyarakat atau orang tua peserta didik, maka kepala PAUD sudah berusaha semaksimal mungkin untuk mendapatkan dana melalui proposal-proposal untuk pembiayaan PAUD, baik itu dari Pemerintah Pusat, Propinsi, dan Kabupaten. Sejauh ini bantuan tersebut sudah cukup dan selalu ada. Bahkan dalam waktu dekat PAUD akan bantuan oprasional pendidikan (BOP) dari pemerintah dalam rangka meningkatkan mutu pembelajaran PAUD.

Pembiayaan meliputi jenis, sumber, dan pemanfaatan, serta pengawasan dan pertanggung jawaban dalam penyelenggaraan dan pengembangan lembaga PAUD yang dikelola secara baik dan transparan.

a. Jenis dan Pemanfaatannya:

1. Biaya investasi, dipergunakan untuk pengadaan sarana prasarana, pengembangan SDM, dan modal kerja tetap.

2. Biaya operasional, digunakan untuk gaji pendidik dan tenaga kependidikan serta tunjangan yang melekat, bahan atau peralatan pendidikan habis pakai dan biaya operasional pendidikan tak langsung.

3. Biaya personal, meliputi biaya pendidikan yang dikeluarkan oleh peserta didik dalam mengikuti proses pembelajaan.

b. Sumber Pembiayaan

Biaya investasi, operasional, dan personal dapat diperoleh dari pemerintah, pemerintah daerah, yayasan, partisipasi masyarakat dan atau pihak lain yang tidak mengikat. 
Jadi dapat disimpulkan bahwa manajemen keuangan sudah dilakukan oleh pihak PAUD dan sudah sesuai dengan petunjuk dan aturan yang tentang pembiayaan penyelenggaraan PAUD. Manajemen keuangan PAUD, juga sudah dikomunikasikan dengan dengan orang tua, peserta didik, dan masyarakat, sehingga tidak ada penolakan dari masyarakat.

\section{Kesimpulan}

Simpulan penelitian menunjukkan bahwa perbandingan antara PAUD Terpadu Negeri Pembina dengan PAUD Pertiwi banyak terdapat persamaanpersamaan dalam rangka meningkatkan mutu pembelajaran.

Pertama, manajemen kurikulum PAUD sudah dilaksanakan oleh PAUD Terpadu dan PAUD Pertiwi dalam rangka meningkatkan mutu pembelajaran pendidikan anak usia dini yaitu layanan yang disediakan berupa kelompok Taman Kanak-Kanak (TK) dan Kelompok Bermain (KB). Kelompokkelompok layanan tersebut diatur dengan sangat baik oleh kepala PAUD sehingga peserta didik merasa senang dapat bersekolah di PAUD Terpadu dan PAUD Pertiwi, disamping itu penyediaan layanan tersebut sudah memenuhi standar pelayanan peserta didik dan sesuai dengan kebutuhan masyarakat sekitar.

Kedua, manajemen kesiswaan yang dilakukan pada PAUD Terpadu dan PAUD Pertiwi sudah dilakukan dalam pembelajaran untuk pemenuhan tingkat pencapaian perkembangan anak, kepala PAUD sudah merencanakan dengan sangat baik, pembelajaran yang dilakukan yang sesuai dengan kelompok umur peserta didik, dan juga sesuai dengan kebutuhan masyarakat sekitar serta peserta didik itu sendiri.

Ketiga, manajemen pendidik dan tenaga kependidikan pada PAUD Terpadu dan Pertiwi sudah dilakukan dengan cukup baik. Pemenuhan tenaga pendidik dan tenaga Kependidikan untuk memenuhi standar, bahkan melebihi standar yang ada, dengan cara memberi kesempatan pendidik untuk kuliah dan mengikuti diklat. Bahkan untuk melayani peserta didik yang cukup banyak, pihak kepala PAUD, mengatur sedemikian rupa supaya tenaga pendidik yang ada dapat terakomodasi dengan baik.

Keempat, manajemen sarana dan prasarana sudah dilakukan oleh kepala PAUD Terpadu dan PAUD Pertiwi. Sehingga sarana dan prasarana yang ada sekarang sudah lebih dan cukup, baik itu dan segi kuantitas maupun kualitas yang disyaratkan sesuai aturan yang ada. Selain itu prinsip sarana dan prasarana tentang alat yang aman, nyaman, terang, dan memenuhi kriteria kesehatan bagi anak, sesuai dengan tingkat perkembangan anak, memanfaatkan potensi dan sumber daya yang ada sudah terpenuhi.

Kelima, manajemen keuangan sudah dilakukan oleh pihak PAUD Terpadu dan PAUD Pertiwi sudah sesuai dengan petunjuk dan aturan 
tentang keuangan penyelenggaraan PAUD. Pengelolaan keuangan PAUD Terpadu dan Pertiwi, juga sudah dikomunikasikan dengan orang tua, peserta didik, dan masyarakat. Sehingga tidak ada penolakan dari masyarakat.

\section{Daftar Pustaka}

Arifin, Ar-Raisul Karama, and Nur Ainy Fardana. "Peran Pendidik PAUD dalam Mengimplementasikan Pendidikan Karakter Melalui Metode Pembelajaran Sentra dan Lingkaran." Jurnal Psikologi Pendidikan dan Perkembangan 3, no. 3 (2014).

Depdiknas. 2002. Kecerdasan Spiritual Dalam Membantu Prilaku Anak, Buletin PAUD Jurnal Ilmiah Anak Usia Dini Edisi Perdana. Jakarta : Direktorat PAUD Ditjen PLSP.

Depdiknas. 2002. Menata System Menuju Gerakan Masyarakat. Bulletin PAUD Jurnal Ilmiah Anak Dini Usia Edisi Ketiga. Jakarta : Direktorat PAUD Ditjen PLSP.

Lombe, TK PERTIWI. "Jurnal Smart PAUD." Jurnal Smart PAUD 1, no. 1 (2018).

M. Solehuddin, Konsep Dasar Pendidikan pra Sekolah (Bandung: Fakultas Ilmu Pendidikan UPI 1997)

Masitoh, Setiasih, O., Djoehaeni, H., Pendekatan Belajar Aktif di Taman Kanakkanak. (Jakarta: Ditjen Dikti Departemen Pendidikan Nasional. 2003)

Rindaningsih, Ida. "Pengembangan Model Manajemen Strategik Berbasis (beyond center and circle Time) BCCT Pada PAUD." PEDAGOGIA: Jurnal Pendidikan 1, no. 2 (2012): 213-223.

Rozalena, Rozalena, and Muhammad Kristiawan. "Pengelolaan Pembelajaran Paud dalam Mengembangkan Potensi Anak Usia Dini." JMKSP (Jurnal Manajemen, Kepemimpinan, dan Supervisi Pendidikan) 2, no. 1 (2017).

Suharsimi Arikunto, Prosedur Penelitian (Suatu Pendekatan Praktik). (Jakarta : Rineka Cipta. 2002), 237

Surjana, Andyarto. "Efektivitas pengelolaan kelas." Jurnal Pendidikan Penabur 1, no. 1 (2002): 64-80. 
70 | TADBIR : Jurnal Studi Manajemen Pendidikan, Vol. 2, No. 1, 2018

This page belongs to the TADBIR : Jurnal Studi Manajemen Pendidikan TADBIR : Jurnal Studi Manajemen Pendidikan vol. 2 , no. 1, 2018

STAIN Curup - Bengkulu | p-ISSN 2580-3581; e-ISSN 2580-5037 